\title{
Rapid Recovery from COVID-19 Respiratory Failure after treatment with Vasoactive Intestinal Peptide
}

Jihad Georges Youssef, MD ${ }^{1}$

Mukhtar Al-Saadi, M.D. ${ }^{2}$

Faisal Zahiruddin, D.O. ${ }^{2}$

Simon Yau, M.D. ${ }^{3}$

Ahmad Goodarzi, M.D. ${ }^{3}$

Howard J. Huang, M.D. ${ }^{3}$

Matthew J, Javitt, MD ${ }^{4}$

Jonathan C. Javitt, MD, MPH ${ }^{5,6}$

Author Affiliations:

1. Houston Methodist Pulmonary Transplant Center, Houston Methodist Research Institute, Houston Methodist Hospital, Houston, Texas, USA

2. Department of Academic Pulmonology, Houston Methodist Hospital, Houston, Texas

3. Houston Methodist Pulmonary Transplant Center, Houston Methodist Research Institute, Houston Methodist Hospital, Houston, Texas, USA

4. NYU Langone Brooklyn Medical Center, Brooklyn, NY

5. NeuroRx, Inc. Wilmington, DE

6. Johns Hopkins University, Baltimore, MD

\section{Keywords}

Vasoactive Intestinal Peptide, VIP, SARS-CoV-2, COVID-19, Acute Respiratory Distress Syndrome, ARDS, Acute Lung Injury, ALI, surfactant, Alveolar Type II

Word Count: 2250

Correspondence to: jjavitt@jhu.edu

Funding: Research support was provided by the Cavendish Impact Foundation. Clinical trial funding was provided by Relief Therapeutics Holdings, AG, Geneva, which holds intellectual property related to the pharmacologic use of Aviptadil.

Disclosure: Author JCJ is employed by a pharmaceutical company that is currently conducting clinical trials of RLF100 in patients with COVID-19 and has a financial interest in the outcome of those clinical trials. Author MJJ was paid for medical writing by NeuroRx, Inc. Author JGY has received funding as an investigator for RLF-100 through his institution. 


\begin{abstract}
Background: Vasoactive Intestinal Peptide (VIP) is known to bind to and protect the Alveolar Type II cell by blocking replication of the SARS-CoV-2 virus, upregulating surfactant production, blocking apoptosis, and blocking cytokine effects. RLF-100 (Aviptadil), a synthetic form of Vasoactive Intestinal Peptide (VIP) has been granted Fast Track Designation and is currently in phase 2/3 placebo-controlled trials. FDA has granted Emergency Use IND and Expanded Access Protocol approval for the use of RLF-100 in patients whose comorbidities render them ineligible for inclusion in the ongoing pivotal trial.
\end{abstract}

Methods: This report describes the first 6 patients with Acute Respiratory Failure in Critical COVID-19, enrolled under Emergency Use IND were treated with three successive 12-hour infusions of intravenous Aviptadil at $50 / 100 / 150 \mathrm{pmol} / \mathrm{kg} / \mathrm{hr}$, while continuing to receive maximal ICU care.

Results: Median patient follow-up time is 14 days. So far, all treated patients have survived. Improved radiographic appearance of typical "ground glass" COVID-19 features to varying degrees is seen in all patients within 72 hours. Improvement in blood oxygenation is seen in all patients, with complete remission from respiratory failure in 4 of 6 patients. An average 56\% reduction in inflammatory markers was seen, together with a median 4 point reduction in the NIAID Ordinal Scale. 2/6 patients were discharged from the hospital and 1 patient was downgraded to the general medicine floor.

Comment: The short term survival of 6/6 patients with respiratory failure in the setting of COVID-19 and major comorbidity is the most dramatic response ever seen with an antiviral agent. Improvement in radiographic appearance, oxygenation requirement, and inflammatory markers is consistent with in vitro evidence of direct antiviral effect.

\title{
Background
}

Vasoactive Intestinal Peptide (VIP) is the first COVID-19 therapeutic shown to block replication of the SARS-CoV-2 virus in human pulmonary epithelial cells and monocytes. ${ }^{1}$ VIP further protects the Alveolar Type II (ATII) cell by upregulating surfactant production, blocking apoptosis, and blocking cytokine effects. In vitro evidence suggests that human monocytes treated with VIP secrete soluble agents that further protect ATII cells via a "bystander effect".

RLF-100 (Aviptadil), a synthetic form of Vasoactive Intestinal Peptide (VIP) has been granted Fast Track Designation and is currently in phase 2/3 placebo-controlled trials (NCT04311697). FDA has granted Emergency Use IND and Expanded Access Protocol approval NCT04453839 for the use of RLF-100 in patients whose comorbidities render them ineligible for inclusion in the ongoing pivotal trial. These comorbidities prognostic for poor outcomes in COVID-19, as enumerated below, were deemed to be sufficiently rare that enrollment could not adequately be balanced within the sample size of the randomized trial.

Since its discovery in 1970 by Said and Mutt ${ }^{2}$ VIP has been shown to protect the lung against a broad array of caustic, immune, and infectious injuries ${ }^{3,4,5,6}$ through its binding to the $\mathrm{VPAC}_{1}$ receptor of the Alveolar Type II cell. This is the same cell to which the SARS-CoV-2 virus binds via the ACE2 receptor ${ }^{7}$. VIP has previously demonstrated effectiveness in the treatment of ARDS related to sepsis ${ }^{8}$ by intravenous administration, sarcoid ${ }^{9}$, and pulmonary hypertension ${ }^{10},{ }^{11}$.

\section{Patients and Methods}

Six patients were identified with PCR-proven COVID-19 and respiratory failure who were ineligible for randomization in the phase $2 / 3$ protocol.

Human subjects protection was overseen by the Institutional Review Board (IRB) of the Houston Methodist Hospital. Patients with Critical COVID-19 and PCR+ diagnosis of SARS-CoV-2 virus infection who were not eligible for NCT04311697 were offered the opportunity to be treated with IV RLF-100 under FDA Emergency Use IND on a named-patient basis. Following informed consent FDA approved the use of Aviptadil (NCT04453839). Following 
informed consent, FDA was contacted prior to the treatment of each patient and approved the use of intravenous RLF100. Drug product was donated by NeuroRx, Inc. (Wilmington, DE).

Each of the patients enrolled in this emergency use program was showing active signs of clinical deterioration at the time of enrollment despite receiving maximal intensive care for COVID-19 related respiratory failure at the Houston Methodist Hospital. The median age of patients was 71 (Interquartile range [IQR] $=25$ years) and there were 3 male and 3 female patients (Table 1). All patients had known chronic diseases. The most common comorbidities prior to admission were hypertension (4/6) and chronic kidney disease (4/6). Two patients have known diabetes mellitus, with Patient 6 being insulin-dependent. Three of the patients had undergone solid organ transplants and were treated with immunosuppressive agents. Patient 2 received a double lung transplant and was treated for antibody-mediated rejection (AMR) one month before presentation. Patient 1 was also diagnosed with a non-ST-elevation myocardial infarction (NSTEMI) during her admission (Table 1). All patients had lab values suggestive of diffuse inflammatory processes including elevated ferritin (5/6), IL-6 (4/6), lactate dehydrogenase (3/6), and C-reactive protein (3/6).

Prior to enrollment, all patients received anticoagulation as well as dexamethasone without remission from respiratory failure. Patients were also treated with remdesivir, tocilizumab, and convalescent plasma as available and per physician discretion. However, supply shortages of these agents were such that only Patient 1 received convalescent plasma before Aviptadil with no clinical improvement following treatment. Following enrollment and informed consent, each patient received three 12-hour intravenous infusions of Aviptadil at graduating doses of 50, 100, and $150 \mathrm{pmol} / \mathrm{kg} / \mathrm{hr}$.

Table 1. Patient characteristics and treatment modalities prior to Aviptadil therapy

\begin{tabular}{|c|c|c|c|c|c|c|}
\hline Patient & Age & Sex & Comorbidities & Presenting Illness & $\begin{array}{l}\text { Treatments Prior } \\
\text { to Aviptadil }\end{array}$ & $\begin{array}{l}\text { Respiratory } \\
\text { Support }\end{array}$ \\
\hline 1 & 71 & $\mathrm{~F}$ & $\begin{array}{l}\text { HTN } \\
\text { CAD s/p CABG in } 2015 \\
\text { CKD }\end{array}$ & $\begin{array}{l}\text {-days diarrhea, } \\
\text { Generalized weakness, } \\
\text { Bilious vomiting, } \\
\text { Dry cough } \\
\text { NSTEMI }\end{array}$ & $\begin{array}{l}\text { Convalescent } \\
\text { plasma } \\
\text { Anticoagulation } \\
\text { Dexamethasone }\end{array}$ & HFNC/NIPPV \\
\hline 2 & 54 & $\mathrm{M}$ & $\begin{array}{l}\text { Rheumatoid arthritis with interstitial } \\
\text { lung disease, } \\
\text { S/p double lung transplant (2019), } \\
\text { Subclinical AMR } \\
\text { Pulmonary HTN } \\
\text { CKD }\end{array}$ & $\begin{array}{l}\text { Dyspnea, Fever } \\
\text { Hypoxemia }\end{array}$ & $\begin{array}{l}\text { Tocilizumab } \\
\text { Dexamethasone } \\
\text { Anticoagulation }\end{array}$ & HFNC \\
\hline 3 & 77 & $\mathrm{M}$ & $\begin{array}{l}\text { Pulmonary fibrosis } \\
\text { S/p left lung transplant (May 2020), } \\
\text { Contracted COVID in Rehab } \\
\text { Facility } \\
\text { HTN }\end{array}$ & $\begin{array}{l}\text { Respiratory distress } \\
\text { Hypogammaglobulinemia } \\
\text { Hypoxemia } \\
\text { Shock } \\
\text { AKI }\end{array}$ & $\begin{array}{l}\text { Dexamethasone } \\
\text { Tocilizumab } \\
\text { CRRT } \\
\text { Nitric oxide } \\
\text { Anticoagulation }\end{array}$ & Ventilator \\
\hline 4 & 71 & $\mathrm{~F}$ & $\begin{array}{l}\text { HTN } \\
\text { DM }\end{array}$ & $\begin{array}{l}\text { Dry cough, Dyspnea, } \\
\text { Hypoxemia (SaO2 90\%), } \\
\text { Fever } 102 \mathrm{~F} \\
\text { AKI }\end{array}$ & $\begin{array}{l}\text { Tocilizumab } \\
\text { Dexamethasone } \\
\text { Anticoagulation }\end{array}$ & Ventilator \\
\hline 5 & 49 & $\mathrm{~F}$ & $\begin{array}{l}\text { CKD s/p kidney transplant, on } \\
\text { immunosuppression, } \\
\text { HTN }\end{array}$ & $\begin{array}{l}\text { Chest Pain, Headache, } \\
\text { Dyspnea, Fatigue }\end{array}$ & $\begin{array}{l}\text { Tocilizumab } \\
\text { Dexamethasone } \\
\text { Anticoagulation }\end{array}$ & Ventilator \\
\hline 6 & 81 & $\mathrm{M}$ & $\begin{array}{l}\text { Parkinson's Disease, } \\
\text { Systolic heart failure, } \\
\text { Pulmonary valve vegetations, } \\
\text { CKD } \\
\text { Seizure disorder } \\
\text { Cervical spondylosis } \\
\text { Insulin-dependent } \\
\end{array}$ & $\begin{array}{l}\text { Fever } 102.5 \mathrm{~F} \\
\text { Hypoxemia }\end{array}$ & $\begin{array}{l}\text { Dexamethasone } \\
\text { Tocilizumab } \\
\text { Anticoagulation }\end{array}$ & BiPAP \\
\hline
\end{tabular}




\author{
DM, \\ CAD \\ HTN \\ HLD \\ Recent sepsis (3/2020)
}

\title{
Clinical Results
}

Each patient showed clinical improvement following administration of Aviptadil, as documented on radiographic imaging and blood oxygenation values (Figure 1). In all cases, clearing of the "ground glass" parenchymal changes associated with COVID-19 pneumonitis was apparent and was noted by the radiologists who read the chest x-rays. Similarly, in all cases a marked decrease in oxygen requirement was seen. Four of six patients recovered from respiratory failure and were weaned off of high-flow nasal cannula (HFNC) to low-flow nasal cannula (LFNC) or room air. All patients demonstrated improvement in blood oxygenation. Available data from blood gases showed stark increases in $\mathrm{PaO} 2: \mathrm{FiO} 2$ ratio after the $2^{\text {nd }}$ dose (Median increase $=92.5$, IQR $=74$ ) and at 24 hours after the $3^{\text {rd }}$ dose (Median increase over baseline 84.5, IQR = 110). Three patients achieved ratios greater than 200 during the week following treatment and no patient showed deterioration of oxygenation below baseline during subsequent measurements. Furthermore, all patients showed improvements in inflammatory markers. At present, 3/6 patients have been discharged to home with minimal supplementary oxygen (Table 2).

\begin{tabular}{|c|c|c|c|c|}
\hline Patient 2 & Before Aviptadil & 24-hr post 3rd Dose & 48-hr post 3rd Dose & 2 weeks s/p Aviptadil \\
\hline $\begin{array}{l}\text { Portable } \\
\text { Chest X-Ray }\end{array}$ & & & & \\
\hline $\mathrm{PaO} 2: \mathrm{FiO} 2$ & 146 & 146 & 285.19 & \\
\hline $\mathrm{SaO} 2$ & 98 & 89 & 95 & 97 \\
\hline Ventilation & $\begin{array}{l}\text { HFLNC } 30 \mathrm{~L} / \mathrm{min}, \mathrm{FiO} 2 \\
50 \%\end{array}$ & $6 \mathrm{~L} / \mathrm{min}$ & $2 \mathrm{~L} / \mathrm{min}$ & $2 \mathrm{~L} / \mathrm{min}$ \\
\hline
\end{tabular}

Figure 1 (Representative Radiographic Appearance and blood oxygen saturation before and after treatment. In all 6 patients resolution of "ground glass" parenchymal changes typical of COVID-19 was apparent on chest $\mathrm{x}$-ray and ascertained by radiologist review

A laboratory panel of inflammatory markers, including LDH, troponin, C-reactive protein, ferritin, D-Dimer, and interleukin 6 was obtained prior to and post treatment with aviptadil (figure 2). In all patients, improvement can be seen on each of the inflammatory markers (see online supplement). The largest average percent decrease was seen in C-reactive protein $(88 \%)$ and interleukin $6(84 \%)$. No patient demonstrated an increase in any of the inflammatory markers.

Hospital course and adverse events. The time to ICU discharge ranged from 1 - 14 days in the 4 of 6 patients so far discharged from intensive care (Table 2). No Serious Adverse Events (SAEs), including mortality were recorded. Only one patient developed a drug-related (non-serious) adverse event. Patient 1 developed diarrhea (an expected treatment emergent event associated with VIP) during the third infusion, which was successfully managed with loperamide and fluid replacement. There were various complications in hospital courses following completion of the Aviptadil regimen (Table 2) as would be expected in patients with this degree of comorbidity. For instance, patient 2 was scheduled for discharge to home 3 days following completion of treatment but fell in the hospital and suffered a retroperitoneal bleed which led to a subsequent 10 day course of inpatient care. Patient 4 , who was about to be treated with extracorporeal membrane oxygenation (ECMO) successfully demonstrated improvement in respiratory distress but developed line sepsis with confirmed $S$. Epidermidis which has led to chronic respiratory distress and continued ventilation. Patient 4's hospital course was complicated by an apical pneumothorax attributed to prone positioning that occurred 24 hours after completing Aviptadil therapy. The pneumothorax spontaneously resolved after discontinuation of prone positioning and no chest tube was required. Vasopressors were administered for continued Youssef JG et al. VIP in COVID-19 Respiratory Failure 
acidosis and hypotension and were subsequently weaned. The patient was started on inhaled nitric oxide and CRRT. The patient had slow clinical and radiologic improvement but remains in the ICU requiring intermittent ventilatory support.

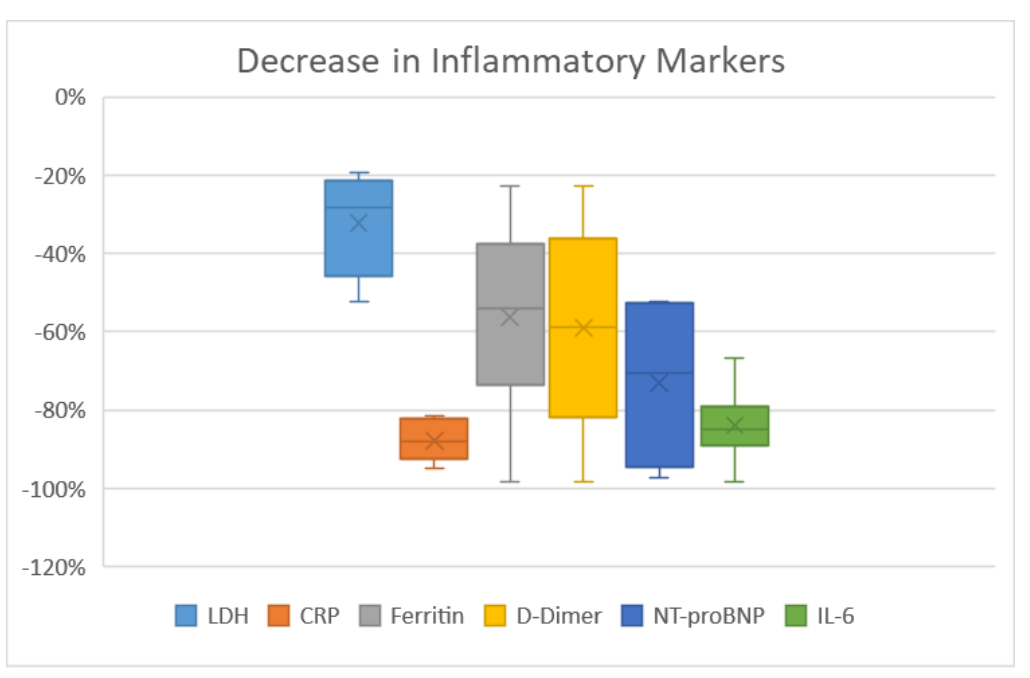

Figure 2: Decrease in Inflammatory Markers seen following treatment with Aviptadil. In all patients, all markers were seen to decrease following treatment (see on-line supplementary material).

Table 2. Hospital course and current disposition of patients following treatment with Aviptadil

\begin{tabular}{|c|c|c|c|c|c|c|}
\hline Patient & Side Effects & $\begin{array}{l}\text { Time to } \\
\text { Resolution of } \\
\text { Respiratory } \\
\text { Failure } \\
\end{array}$ & $\begin{array}{l}\text { Time to ICU } \\
\text { Discharge }\end{array}$ & $\begin{array}{l}\text { Time to } \\
\text { Hospital } \\
\text { Discharge }\end{array}$ & Current Disposition & $\begin{array}{l}\text { Respiratory } \\
\text { Support } \\
\end{array}$ \\
\hline 1 & Diarrhea & 15 days & 14 days & 32 days & Discharged to home & $\begin{array}{l}\text { LFNC with } \\
\text { exertion }\end{array}$ \\
\hline 2 & None & 3 day & 1 day & 3 days & Discharged to home & $\begin{array}{l}\text { LFNC with } \\
\text { exertion }\end{array}$ \\
\hline 3 & None & & & & $\begin{array}{l}\text { ICU } \\
\text { s/p tracheostomy } \\
\text { CRRT } \\
\text { Respiratory Muscle } \\
\text { Weakness }\end{array}$ & Ventilator \\
\hline 4 & None & & & & $\begin{array}{l}\text { ICU } \\
\text { CRRT } \\
\text { Prolonged ventilation } \\
\text { from pneumothorax }\end{array}$ & Ventilator \\
\hline 5 & None & 12 days & 9 days & & Discharged to floor & LFNC \\
\hline 6 & None & 3 days & 3 days & & $\begin{array}{l}\text { Ready for discharge, } \\
\text { awaiting placement }\end{array}$ & LFNC \\
\hline
\end{tabular}

\section{$\underline{\text { Discussion }}$}

This is the first reported treatment of Acute Respiratory Failure in patients with Critical COVID-19 using Vasoactive Intestinal Peptide (Aviptadil). The six patients in this report had serious comorbidities that made them ineligible for participation in the ongoing FDA phase 2/3 pivotal study of RLF-100 (aviptadil) in the treatment of COVID-19 respiratory failure. All six patients demonstrated rapid clinical improvement in both blood oxygenation and radiographic features, although respiratory failure persists in 2 of the 6 patients. The substantial decrease in inflammatory markers seen in all patients, particularly in ferritin, D-Dimer, and IL6 which are increasingly associated 
with poor prognosis in COVID-19 suggests that the radiographic and oxygenation improvement seen in these patients may be tied to an etiologic effect of Aviptadil. The fact that all patients have, so far, survived is highly unexpected in COVID-19 patients with this degree of comorbidity and the fact that four of the six have been discharged from acute care is equally remarkable. Patient 3 remains on mechanical ventilation not because of oxygenation failure but rather because of respiratory muscle weakness. Patient 4 was scheduled for extubation when a pneumothorax developed requiring additional ventilatory support.

This is the second similarly-sized case series in which aviptadil has been associated with a remarkable degree of improvement in patients with Acute Respiratory Distress. In the 2005 time frame, 8 patients with sepsis-related Acute Respiratory Distress Syndrome were treated with the same intravenous protocol. ${ }^{12}$ All 8 patients demonstrated clinical improvement, 7 were discharged from intensive care and life support was terminated in the $8^{\text {th }}$ for neurologic, rather than pulmonary reasons. Although the case series was not reported until recently because of the retirement and subsequent demise of the senior author, the clinical care was managed and results recorded by one of our authorship (JGY). Similar clearing of pneumonitis with aviptadil (delivered by nebulizer) was recently reported in a patient with checkpoint inhibitor pneumonitis. ${ }^{13}$

Early COVID-19 lung injury is characterized by a remarkable degree of hypoxemia in the absence of overwhelming pneumonia, suggesting a primary injury to the pulmonary gas-exchange mechanism.

Although named (or mis-named) for the gut where it was first isolated, 70\% of VIP is localized to the lung and binds primarily to Alveolar Type II cells (ATII) cells via VPAC $1 .{ }^{14}$ ATII cells comprise only $5 \%$ of the pulmonary epithelium but are critical to surfactant production and recycling as well as the maintenance of type I epithelial cells. The SARS-CoV-2 virus specifically attacks ATII via their ACE2 surface receptors and does not enter the Type I pneumocyte. ${ }^{15}$ VIP preserves the function of lung allografts and may have been particularly beneficial in this patient who was suffering active graft rejection. ${ }^{16,17}$

Unlike synthetic anti-cytokines, such as anti-IL6 drugs, VIP is shown to have a specific role in preserving surfactant production in the lung. ${ }^{18,19,20,21}$ Accordingly, VIP and longer acting modifications of VIP have been proposed in the past as respiratory therapeutics ${ }^{22}$. Li demonstrated in rat lung explants that VIP increased the incorporation of methylcholine into phosphatidylcholine -- the major component of the pulmonary surfactants -- by enhancing the activity of the enzyme choline-phosphate cytidylyltransferase ${ }^{16}$. VIP upregulates C-Fos protein expression in cultured type II alveolar cells, which is instrumental in promoting synthesis of pulmonary surfactant phospholipids ${ }^{17}$ and induces surfactant protein A expression.

\section{Conclusion:}

The rapid clinical improvement seen in these six patients treated with intravenous RLF-100 (Aviptadil), is consistent with the finding that VIP not only blocks viral replication in the pulmonary epithelium but creates a "bystander effect" whereby nearby monocytes secrete soluble antiviral agents to further protect ATII cells, blocks cytokine storm, and improves oxygenation in a lung that is under attack by the SARS-CoV-2 virus. This highly specific role of VIP in the lung may be key to combating the lethal effects of SARS-CoV-2 infection. A randomized prospective trial is underway, which will attempt to demonstrate that intravenous RLF-100 improves survival, oxygenation, and clinical course of Critical COVID-19 with respiratory failure. The independent Data Monitoring Committee of that trial has conducted the first unblinded look at the study data and identified no safety signals. Moreover, the DMC has determined that the study is not futile in its objective to identify a statistically significant difference between aviptadil and placebo in remission from COVID-19 respiratory failure.

The patients reported here were deemed too ill to be randomized in the ongoing phase $2 / 3$ clinical trial of RLF- 100 for treatment of Critical COVID-19. Yet their clinical course, particularly the rapidity with which resolution in COVID pneumonitis with improvement in oxygenation and radiographic appearance within days is highly atypical for COVID-19 and suggests that Aviptadil has substantial potential to demonstrate clinical effectiveness in placebocontrolled trials. 
1 Temerozo JR, Sacramenta Q, Fintelman-Rodriques N, et. al. The neuropeptides VIP and PACAP inhibit SARS-CoV-2 replication in monocytes and lung epithelial cells, decrease the production of proinflammatory cytokines, and VIP levels are associated with survival in severe Covid-19 patients doi: https://doi.org/ I 0.I I 0 I/2020.07.25.220806

${ }^{2}$ Said SI, Mutt V. Potent peripheral and splanchnic vasodilator peptide from normal gut. Nature. 1970; 225: 863-864.

${ }^{3}$ Said SI. Vasoactive intestinal peptide in the lung. Ann NY Acad Sci 1988;527:450-464

${ }^{4}$ Said SI. VIP as a modulatory of lung inflammation and airway constriction Am Rev Respir Dis 1991;143:S22-S24.

${ }^{5}$ Said SI, Dickman KG. Pathways of inflammation and cell death in the lung: modulation by vasoactive intestinal peptide. Regul. Pept. 2000;93:21-29

${ }^{6}$ Javitt JC. Perspective: The potential role of vasoactive intestinal peptide in treating COVID-19. Authorea May 13, 2020 DOI: $10.22541 / \mathrm{au} .158940764 .42332418$

${ }^{7}$ Mason R. Pathogenesis of COVID-19 from a cell biologic perspective. Eur Respir J. April 9 Epub ahead of print. https://www.ncbi.nlm.nih.gov/pmc/articles/PMC7144II60/

${ }^{8}$ Youssef JG, Said S, Youssef G, Javitt MJ, Javitt JC. Vasoactive Intestinal Peptide in the treatment of Acute Respiratory Distress Syndrome. Lancet 2020, under review.

${ }^{9}$ Prasse A, Zissel G, Lützen N, Schupp J, Schmiedlin R, Gonzalez-Rey E, Rensing-Ehl A, Bacher G, Cavalli V, Bevec D, Delgado M, Müller-Quernheim J. Inhaled vasoactive intestinal peptide exerts immunoregulatory effects in sarcoidosis. Am J Respir Crit Care Med. 2010;182:540-8

${ }^{10}$ Petkov V, Mosgoeller W, Ziesche R, Raderer M, Stiebellehner L, Vonbank K, Funk GC, Hamilton G, Novotny C, Burian B, Block LH. Vasoactive intestinal peptide as a new drug for treatment of primary pulmonary hypertension. J. Clin. Invest 2003;111:1339-1346.

${ }^{11}$ Leuchte HH, Baezner C, Baumgartner RA, et. al. Inhalation of vasoactive intestinal peptide in pulmonary hypertension. Eur Respir J 2008;32:1289-1294.

12 Youssef, J.G.; Said, S.; Youssef, G.; Javitt, M.J.; Javitt, J.C. Treatment of Acute Respiratory Distress Syndrome with Vasoactive Intestinal Peptide. Preprints 2020, 2020070453 (doi: 10.20944/preprints202007.0453.v1).

${ }^{13}$ Frye BC, Meiss F, von Bubnoff D, Zissel G, Muller-Quernheim J. Vasoactive intestinal peptide in checkpoint inhibitor-induced pneumonitis. N Engl J Med 2020;382:26

${ }^{14}$ Virgolini I, Kurtaran A, Raderer M, et. al. Vasoactive Intestinal Peptide Receptor Scintigraphy. J Nucl Med 1995:36(10):1732-1739

${ }^{15}$ Mossel EC, Wang J, Jeffers S, et al. SARS-CoV replicates in primary human alveolar type II cell cultures but not in type I-like cells. Virology 2008;372:127-135.

${ }^{16}$ Alessandrini, F., Thakkar, M., Foda, H.D., Said, S.I., Lodi, R., Pakbaz, H., and Schraufnagel, D.E. Vasoactive intestinal peptide enhances lung preservation. Transplantation 1993;56:964-973

${ }^{17}$ Pakbaz H, Berisha H, Sharaf H, Foda HD, Said SI. VIP enhances and nitric oxide synthase inhibitor reduces survival of rat lungs perfused ex vivo. Ann. N. Y. Acad. Sci. 1994;723:426-428

${ }^{18} \mathrm{Li}$, L., Luo, Z.Q., Zhou, et. al. Effect of vasoactive intestinal peptide on pulmonary surfactants phospholipid synthesis in lung explants. Acta Pharmacol. Sin. 2004;25:1652-1658

${ }^{19} \mathrm{Li}$ L, She H, Yue S, et. al. Role of C-Fos gene in vasoactive intestinal peptide promoted synthesis of pulmonary surfactant phospholipids. Regul Pept 2007;140(3):117-124

${ }^{20} \mathrm{Li}$ L, Hua S, Yue S, Luo Z, et. al., Vasoactive intestinal polypeptide induces surfactant protein A expression in ATII cells through activation of PKC/c-Fos pathway. Peptides 2010;31(11):2016-2051 
${ }^{21}$ Onoue S, Ohmori Y, Endo K, Yamada S, Kimura R, Yajima T. Vasoactive intestinal peptide and pituitary adenylate cyclase-activating polypeptide attenuate the cigarette smoke extract-induced apoptotic death of rat alveolar L2 cells. Eur. J. Biochem. 2004;271: 1757-1767.

${ }^{22}$ Mathioudakis AG, Chatzimavridou-Grigoriadou V, Evangelopoulou E, Mathioudakis GA. Vasoactive Intestinal Peptide Inhaled Agonists: Potential Role in Respiratory Therapeutics. Hippokratia 2013;17(1):12-16 